\title{
Bacterivory by benthic ciliates: significance as a carbon source and impact on sediment bacteria
}

\author{
Paul F. Kemp \\ Oceanographic Sciences Division, Brookhaven National Laboratory, Upton, New York 11973, USA
}

\begin{abstract}
Protozoan bacterivory is generally recognized as an important process influencing bacterial abundance in pelagic ecosystems, and as a possible pathway for transfer of bacterial production to metazoans. The present study examines the role of ciliated protozoa as bacterivores in shallow-water benthic systems. Bacterivory would support reasonable growth rates for smaller ciliates in saltmarsh and saline pond sediments, whereas ingestion rates of larger ciliates were too low to support reasonable growth rates. Predicted ciliate bacterivory in saltmarsh, saline pond and mangrove sediments would account for less than $4 \%$ of bacterial abundance per day or of minimum hourly bacterial production. In order for ciliate bacterivory to control bacterial abundance in sediment, ciliates must be very much more abundant or ingest bacteria at very much higher rates than measured in this study. These results suggest that benthic ciliated protozoa are minor vectors for direct transfer of bacterial production to metazoan food webs.
\end{abstract}

\section{INTRODUCTION}

Bacterial production is the largest component of heterotrophic production in most marine sediments (Kemp 1987, 1989), yet very little is known of the fate of benthic bacterial production. Sediment-ingesting macrofauna are unable to consume more than a small fraction of bacterial production (Kemp 1987). We can hypothesize that the majority of benthic bacterial production is consumed by protozoan grazers in a manner analogous to pelagic microbial food webs (Azam et al. 1983). In common with pelagic food webs, protozoan grazing may represent a sink for the majority of benthic bacterial production and possibly a link to metazoan food webs. With regard to the latter, the proportion of bacterial production indirectly available to sedimentingesting fauna via bacterivorous protozoa would depend on the biomass of protozoa relative to that of bacteria, and on the proportion of protozoan biomass supported by bacterivory.

Recently introduced techniques allow quantitative evaluation of the importance of benthic protozoa as bacterivores. Short-term protozoan grazing can be measured using monodispersed (i.e. predominantly present as single particles), fluorescent latex microspheres (Borsheim 1984) or more recently monodispersed, fluorescently-labelled bacteria (FLB; Sherr et al. 1987). In this study ciliate grazing measured by the
FLB method was compared to bacterial production measured by the incorporation of tritiated thymidine into DNA. This initial study focused on ciliates rather than other bacterivorous protozoa because ciliates have been shown to be important bacterivores in coastal marine water (Sherr \& Sherr 1987) and their potential importance as bacterivores in sediment has been suggested previously (Fenchel 1980).

\section{MATERIALS AND METHODS}

Samples of aerobic surface sediment were collected in 3 locations: intertidally from a Spartina alterniflora saltmarsh (Sapelo Island, Georgia, USA); subtidally from a mangrove (Rhizophora mangle) creek bank (Chub Cay, Bahamas); and from a landlocked saline pond (Chub Cay, Bahamas). Surface sediment at the saltmarsh site was organic-rich mud and consisted of flocculent fine particles; this surficial layer is partially resuspended by currents and fiddler crab disturbance at high tide. Sediment at the mangrove site was loosely packed, medium-coarse sand mixed with leaf fragments. The organic-rich saline pond sediment consisted of flocculent particles mixed with large numbers of intact fecal pellets of unidentified origin. Saltmarsh sediment was collected in August 1986 by scraping off the 0 to $5 \mathrm{~mm}$ surface layer at low tide or pipetting at 
high tide, mangrove sediment in October 1986 by diving at low tide and scraping off the 0 to $10 \mathrm{~mm}$ surface layer at $1.5 \mathrm{~m}$ water depth, and saline pond sediment in October 1986 by scraping off the 0 to $10 \mathrm{~mm}$ surface layer at approximately $50 \mathrm{~cm}$ water depth. Care was taken to minimize mixing of surficial sediment with overlying water or underlying anaerobic sediment.

In all sediments, $5 \mathrm{~s}$ of low-speed vortex mixing sufficed to disperse added FLB or thymidine. It was assumed that slurrying of the shallow surficial layers of sediment, which in fine sediments are normally subject to resuspension, introduced no serious artifacts in measurements of bacterial production or protozoan ingestion rates. While this assumption has been validated for bacterial production measurements using the thymidine method (Pollard \& Moriarty 1984), the effects of sediment slurrying on protozoan grazing have not been examined. Incubations were conducted in the laboratory or on shipboard at the temperatures and salinities measured at the time of collection (27 to $29^{\circ} \mathrm{C}, 25$ to $\left.30 \% \mathrm{~S}\right)$.

Bacterial production was estimated using a modified version of the thymidine method of Moriarty \& Pollard (1981, 1982), in which the incorporation of tritiated thymidine into the DNA fraction of extractable macromolecules was measured. Incubation times of $4 \mathrm{~min}$ were used, since preliminary time course experiments indicated linear uptake of thymidine for not more than 6 min in saltmarsh and saline pond sediments. Uptake was corrected for abiotic absorption in formalin-killed controls. It was frequently not possible to saturate uptake of thymidine at concentrations up to $2000 \mathrm{~nm}$ thymidine; consequently, thymidine incorporation at lower concentrations (75 or $225 \mathrm{~nm}$ thymidine) was used to calculate bacterial production. Production estimates reported in Table 1 were not corrected for DNA extraction efficiency (DNA fraction of baseextractable macromolecules; efficiency probably $50 \%$ or less) or for isotope dilution by sources of thymine in the sediment (e.g. de novo bacterial synthesis; Moriarty \& Pollard 1981). Correcting for these factors (non-saturation, incomplete extraction, and isotope dilution) would in each case increase estimates of bacterial production. The uncorrected production estimates reported herein therefore underestimate bacterial production by at least a factor of 2 and probably by a substantially greater amount. For the present study, a minimum production estimate was sufficient for comparison to ciliate ingestion rates.

Ingestion of bacteria by ciliates was measured by adding heat-killed bacteria (FLB) stained with dichlorotriazenylaminofluorescein (DTAF; Sherr et al. 1987) to sediment and incubating for $30 \mathrm{~min}$ at in situ temperatures and salinities. The FLB source was a monospecific culture of short rod-shaped bacteria iso- lated from a freshwater pond (Sherr et al. 1987), with a generally uniform equivalent spherical diameter of 0.6 $\mu \mathrm{m}$, similar to the mean size of sediment bacteria in samples from saltmarsh and saline pond environments. Some digestion of FLB by ciliates may occur after 10 to $20 \mathrm{~min}$ (Sherr et al. 1987) and $30 \mathrm{~min}$ incubations therefore may underestimate grazing rates slightly. FLB were added to sediment at concentrations equal to $25 \%$ of the native bacterial abundance. Bacterial abundance was determined by direct counts of diluted (saltmarsh) or homogenized and diluted (pond, mangrove) sediment preparations stained with diamidinophenylindole (DAPI; Porter \& Feig 1980). In saltmarsh sediment, $0.6 \mu \mathrm{m}$ fluorescent latex microspheres (Polysciences) were added to a separate treatment for comparison with ingestion rates measured using FLB. Incubations were terminated by the addition of formalin ( $2 \%$ formaldehyde final concentration).

A dilute suspension (generally 1:160 dilution) of the sediment was stained with DAPI, filtered onto $0.8 \mu \mathrm{m}$ membrane filters (Nuclepore Corp.) stained with irgalan black, and examined by epifluorescence microscopy. Sediment dilution is 1 of 2 methods shown to yield superior recovery of sediment protozoa (Alongi 1986). Preparations were scanned at $200 \times$ using a DAPI filter set (Zeiss 477702 ) to locate and enumerate heterotrophic ciliates (lacking chlorophyll autofluorescence), and individual ciliates were examined at $1250 \times$ using an acridine orange filter set (Zeiss 477709 ) to measure cell dimensions and enumerate ingested FLB. FLB cells lying on the surface of, or under ciliates were distinguishable from and generally much less numerous than those contained within food vacuoles. Cell dimensions were used to estimate volume based on formulae for comparable geometric solid shapes. Chlorophyll-containing ciliates which had ingested FLB were also counted and measured but were always rare (e.g. $5.3 \%$ of phagotrophic saltmarsh ciliates)

\section{RESULTS}

Ciliates were not routinely identified to taxonomic groups, although scuticociliates and the hypotrich Euplotes sp. were common in intertidal saltmarsh sediment. Of the saltmarsh ciliates $16 \%$ were of a large (average maximum diameter $60 \mathrm{~km}$ ), recognizable scuticociliate taxon which usually contained cyanobacteria within food vacuoles (identifiable by their redorange fluorescence under green-light illumination) but seldom ingested FLB; these also contained few or no native bacteria, which in bacterivorous ciliates were usually visible in food vacuoles when stained with DAPI. Ciliates were unusually abundant in saline pond 
Table 1. Comparison of ciliate abundance and grazing to bacterial abundance and production. Mean values shown with their standard errors, $n$ in parentheses. Saltmarsh sediment immersed at 15:00 h only. Ingestion rates are FLB ingestion converted to total bacterial ingestion

\begin{tabular}{|c|c|c|c|c|c|c|c|}
\hline \multirow[t]{2}{*}{ Sample source (time) } & \multirow{2}{*}{$\begin{array}{c}\text { Bacterial } \\
\text { abundance } \\
10^{9} \text { cell } \mathrm{ml}^{-1}\end{array}$} & \multirow{2}{*}{$\begin{array}{c}\text { Bacterial } \\
\text { production } \\
10^{7} \text { cell } \mathrm{ml}^{-1} \mathrm{~h}^{-1}\end{array}$} & \multirow{2}{*}{$\begin{array}{l}\text { Ciliate } \\
\text { abundance } \\
\text { cells } \mathrm{ml}^{-1}\end{array}$} & \multirow{2}{*}{$\begin{array}{c}\text { Ciliate } \\
\text { ingestion } \\
\text { bact. cell }{ }^{-1} \mathrm{~h}^{-1}\end{array}$} & \multirow{2}{*}{$\begin{array}{l}\% \text { Ciliates } \\
\text { containing } \\
\text { FLB }\end{array}$} & \multicolumn{2}{|c|}{$\begin{array}{c}\% \text { Bacteria } \\
\text { ingested } d^{-1} \text { : }\end{array}$} \\
\hline & & & & & & $\begin{array}{l}\text { produc- } \\
\text { tion }\end{array}$ & $\begin{array}{l}\text { abun- } \\
\text { dance }\end{array}$ \\
\hline Saltmarsh $(09: 00 h)$ & $2.63(0.15,3)$ & $5.54(2.78,3)$ & $1056(270.6,5)$ & $37 \quad(12.1,27)$ & 41 & 0.07 & 0.04 \\
\hline$(12: 00 \mathrm{~h})$ & $2.78(0.12 .3)$ & $1.42(0.38,3)$ & $992(185.2,5)$ & $90 \quad(37.5,31)$ & 61 & 0.63 & 0.08 \\
\hline$(15: 00 h)$ & $1.75(0.05 .3)$ & $1.76(0.80,3)$ & $448(137.7,5)$ & $421(161.8,12)$ & 58 & 1.07 & 0.25 \\
\hline$(18: 00 \mathrm{~h})$ & $2.44(0.20,3)$ & $3.96(1.33,3)$ & $992(198.6,5)$ & $230 \quad(52.8,31)$ & 68 & 0.58 & 0.22 \\
\hline Saline pond $(10: 00 \mathrm{~h})$ & $3.29(0.08,5)$ & $10.67(1.17,3)$ & $7616(457.1,5)$ & $525 \quad(52.0,130)$ & 83 & 3.75 & 2.92 \\
\hline Mangrove $(10: 00 \mathrm{~h})$ & $1.71(0.10,20)$ & $2.65(1.24,3)$ & - & - & - & - & - \\
\hline
\end{tabular}

sediment, with Euplotes sp. and tintinnid ciliates the most common forms; the latter are not considered strictly benthic but in this loosely packed sediment occurred in the sediment interstices. Mangrove creek sediment contained too few ciliates to enumerate by the method used, in agreement with reported very low ciliate abundances in Australian mangrove sediment (Alongi 1986). However, bacterial abundance and pro-
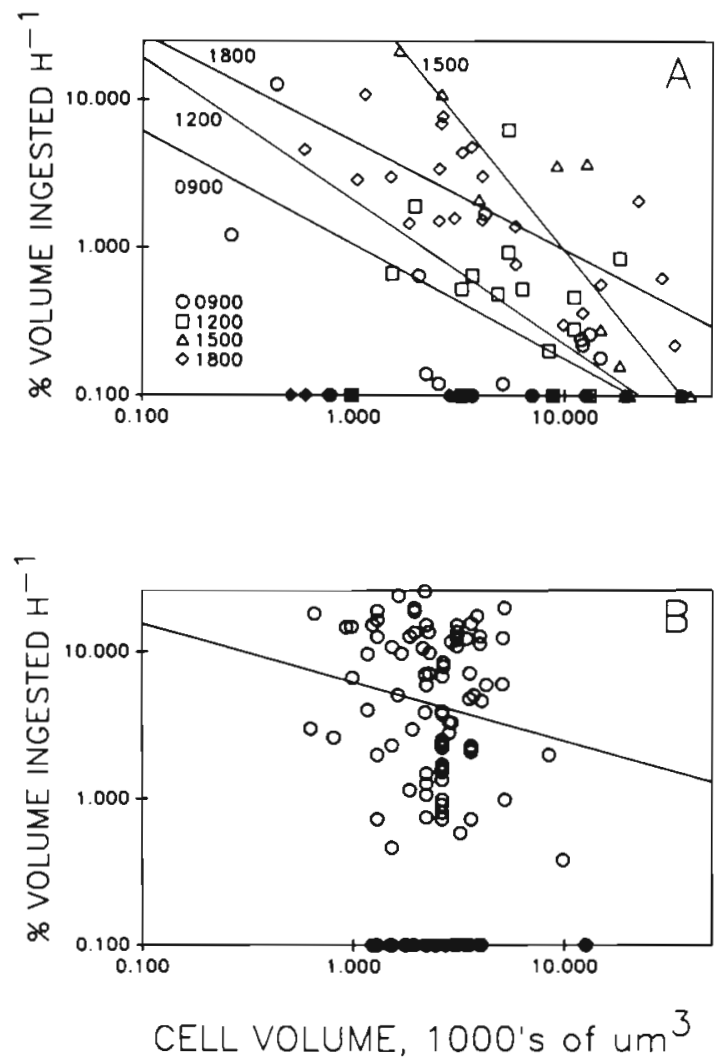

Fig. 1. Ingestion rate (FLB ingestion converted to total bacterial ingestion) expressed as \% ciliate volume $\mathrm{h}^{-1}$ Distribution of ciliates which ingested zero FLB shown as filled symbols along abscissa. (A) Saltmarsh sediment; (B) saline pond sediment. Significant regressions shown $(p<0.05)$ duction were measured in mangrove sediment (Table 1) for comparison with the literature data.

Ingestion rates varied significantly (ANOVA, $p<0.001$ ) with sampling time in intertidal saltmarsh sediment (Table 1), with the maximum ingestion rate occurring in samples collected at high tide. Saltmarsh ciliates ingested 0.1 to $15.0 \%$ (daily average $=1.96 \%$, $\mathrm{SE}=0.50 \%, n=4$ sampling times) and saline pond ciliates ingested 0.5 to $25 \%$ (average $=5.87 \%, \mathrm{SE}=$ $0.60 \%, n=117$ ciliates) of their body volume per hour.
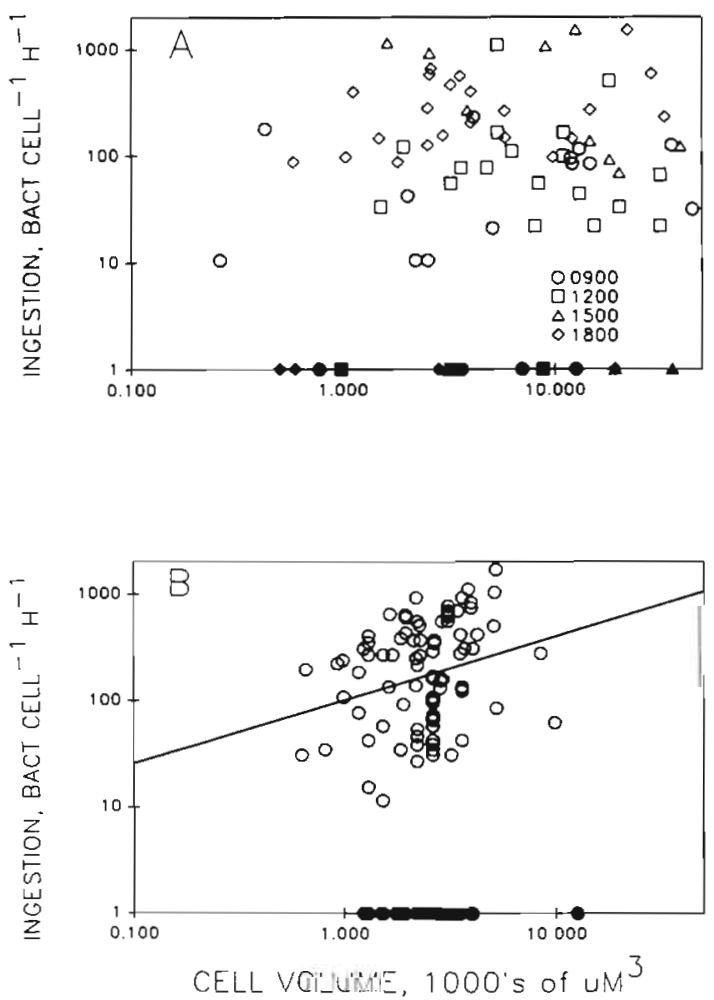

Fig. 2. Ingestion rate (FLB ingestion converted to total bacterial ingestion) expressed as bacteria ciliate ${ }^{-1} \mathrm{~h}^{-1}$. Distribution of ciliates which ingested zero FLB shown as filled symbols along abscissa. (A) Saltmarsh sediment; (B) saline pond sediment. Significant regressions shown $(p<0.05)$ 
Ingestion rates of bacterivorous saltmarsh ciliates declined significantly with increasing biovolume (Fig. $1 \mathrm{~A}_{i}$ linear least-squares regressions for each sampling time, $r=0.74-0.89$, all $p<0.001$ ). There was also a marginally significant decline in saline pond sediment (Fig. $1 \mathrm{~B}_{i} r=0.21, p=0.05$ ), although only a very small fraction of the variance was explained by regression. In terms of number of bacterial cells ingested per hour, ingestion rates varied widely for ciliates of a given size (Fig. 2A, B), with a significant although slight increase in ingestion rate with increasing ciliate volume in saline pond sediment $(r=0.35, p<0.001)$. Again only a small fraction of total variance was explained by regression.

In saltmarsh sediment, ingestion rates measured using latex microspheres were comparable to those measured at approximately the same time using FLB (mean ingestion rate $=72$ bacteria-sized particles cell ${ }^{-1} \mathrm{~h}^{-1}$ at 10:00 h), in contrast with reported strong selectivity of some pelagic ciliates in favor of FLB over latex microspheres (Sherr \& Sherr 1987).

\section{DISCUSSION}

While there is recent evidence that aldehyde preservatives may induce expulsion of food vacuole contents in microflagellates, this has not been reported as a problem with ciliates (Sieracki et al. 1987). Relatively high percentages of cells with recently ingested FLB (Table 1) suggest that aldehyde preservation was satisfactory in this study.

The measured ingestion rates, as percent of ciliate volume per hour, were comparable to ingestion rates measured for planktonic suspension-feeding ciliates feeding at suboptimal bacterial concentrations (Rivier et al. 1985), but much less than maximum ingestion rates estimated for various ciliates feeding on bacteriasized particles under optimal conditions (Fenchel 1980, Rivier et al. 1985). Fenchel (1975) estimated that benthic bacterivorous ciliates in a tundra pond environment ingested bacterial biomass approximately equivalent to $25 \%$ of their own carbon biomass per day, which is comparable to the median volume-based ingestion rates in both saltmarsh and saline pond sediments (allowing for substantially greater carbon per volume in bacteria than in ciliates; see values cited below). The ingestion rates measured in this study appear reasonable by comparison with published data. The present data are insufficient to determine whether these benthic ciliate assemblages were feeding at suboptimal rates or whether optimal rates for benthic ciliates are characteristically lower than for pelagic suspension-feeding ciliates.

Ingestion rates (\% ciliate biovolume $\left.\mathrm{h}^{-1}\right)$ declined substantially with increasing ciliate biovolume in saltmarsh sediment. Some decrease in ingestion rate is expected due to decreasing biomass-specific metabolic rate with increasing biomass; the slope of this decrease should be near -0.27 for pelagic suspension-feeding ciliates (Fenchel 1980). In saltmarsh sediment, the actual slopes ranged from $-0.73(09: 00 \mathrm{~h})$ to -1.73 $(15: 00 \mathrm{~h})$. The implication is that factors other than metabolic costs result in a greater-than-expected decrease in ingestion rate with increasing size. An obvious possibility is that larger ciliates may ingest bacteria but fed preferentially on other particles such as larger bacteria or algae. For example, in saltmarsh sediment a common ciliate taxon averaging $40 \mu \mathrm{m}$ equivalent spherical diameter, or 4 times the mean biovolume, ingested coccoidal cyanobacteria but not FLB. In saline pond sediment the decrease in ingestion rate with increasing ciliate volume was only marginally significant, possibly because of the lesser range in cell biovolume present.

Given the following assumed conversion factors, the reproduction rate which could be supported by bacterivory can be estimated. Bacterial carbon was assumed to equal $0.22 \mathrm{~g} \mathrm{C} \mathrm{cm}^{-3}$ (Bratbak \& Dundas

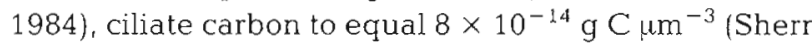
\& Sherr 1984) and gross growth efficiency to equal $33 \%$ (Sherr et al. 1986a). The daily average ingestion rate in saltmarsh sediment $\left(5.25 \mathrm{pg} \mathrm{C}\right.$ ciliate ${ }^{-1} \mathrm{~h}^{-1}$ ) would support one doubling of total heterotrophic ciliate biomass per $20.9 \mathrm{~d}$, much longer than doubling times generally observed for pelagic ciliates (Heinbokel 1978, Rivier et al. 1985, Jonsson 1986, Sherr et al. 1986b). This comparison would indicate that ciliate bacterivory supports a minor fraction of growth in saltmarsh sediment. However, when the effect of ciliate size on ingestion rate is considered the conclusion is rather different. For example, for smaller ciliates (less

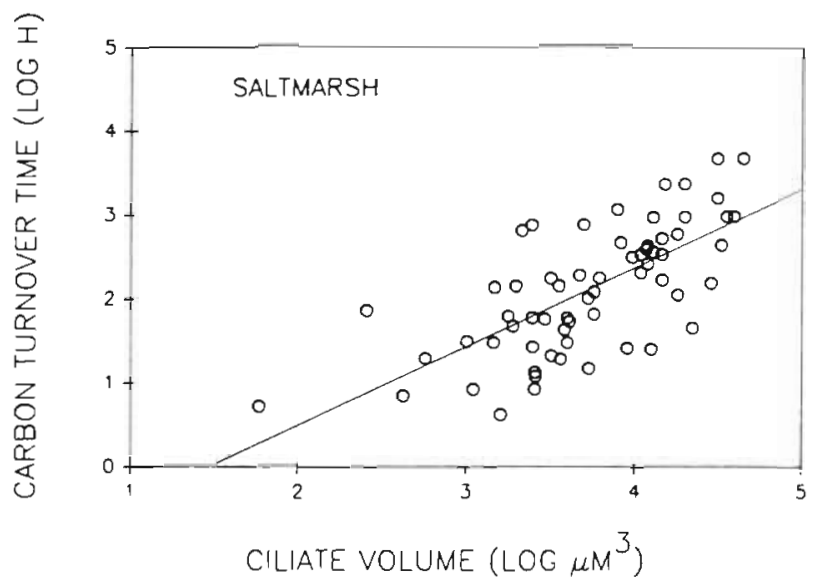

Fig. 3. Tumover time for carbon which could be supported by bacterivory at $33 \%$ gross growth efficiency in saltmarsh sediment 
than an arbitrary size cutoff of $25 \mu \mathrm{m}$ equivalent spherical diameter) the average ingestion rate in saltmarsh sediment would support one doubling per $2.1 \mathrm{~d}$. This is reasonable for ciliates feeding at somewhat suboptimal rates (cf. Rivier et al. 1985). For ciliates larger than $25 \mu \mathrm{m}$ equivalent spherical diameter, the average daily ingestion rate would only support one doubling every $40.9 \mathrm{~d}$.

Based on the assumptions detailed above, ingestion rates can be expressed as the equivalent percent of ciliate carbon incorporated per hour, and therefore also as the hours required to turn over $100 \%$ of cell carbon (taking into account a $33 \%$ gross growth efficiency). The carbon turnover time which could be supported by bacterivory was plotted against ciliate volume (Fig. 3); the regression describing this relationship for all saltmarsh ciliates which had ingested bacteria is:

$\log ($ hours required $)=0.924 \log ($ volume $)-1.2579$,

with $r=0.69$ (for slope, $p<.001$ ); $n=65$. It should be emphasized that while the slope of this relationship is statistically significant, data variability is substantial; ingestion rates and consequently turnover times vary over nearly 2 orders of magnitude for cells of a given volume. The regression should also be regarded as potentially subject to inherent systematic errors in the assumptions used to generate the data. For example: the use of geometric solid formulae to estimate biovolume is likely to overestimate volume; gross growth efficiency (estimated here at $33 \%$ ) may be higher, as reported for other protozoa (Fenchel 1986), resulting in shorter turnover times; selection for native bacteria larger or smaller than the FLB would decrease or increase turnover times; and selection for or against FLB relative to native bacteria would increase or decrease turnover times. Consequently, the descriptive regression above should not be used predictively, for example to estimate the size range of ciliates which can be entirely supported by bacterivory. The regression slope does, however, demonstrate that bacterivory in saltmarsh sediment tends to decrease rapidly (with increasing cell size) in its importance as a carbon source.

In saline pond sediment, few ciliates were large and there was only a weak relationship between ingestion rate and cell biovolume. Under the same assumptions, ciliate bacterivory would support one doubling of heterotrophic ciliate biomass per $2.6 \mathrm{~d}$. Based on data from these 2 sampling sites, ciliate bacterivory in sediment should support reasonable growth rates for smaller ciliates. Although a majority of both small and larger ciliates were bacterivorous (i.e. ingested FLB), bacteria appear to be a supplementary food resource rather than a primary carbon source for the larger bacteriaingesting ciliates.
Perhaps the most significant conclusion of this study is that ciliates should have little direct effect on bacterial abundance, consuming about $1 \%$ or less of bacterial abundance (per day) and of minimum hourly bacterial production in intertidal saltmarsh sediment, and less than $4 \% \mathrm{~d}^{-1}$ of bacterial abundance or minimum hourly bacterial production in saline pond sediment (Table 1). In mangrove sediment, using published abundance data (ca 50 ciliates $\mathrm{ml}^{-1}$; Alongi 1986) and a reasonable ingestion rate (ca 260 bacteria cell ${ }^{-1} \mathrm{~h}^{-1}$; mean of all saltmarsh and saline pond data), ciliates would ingest less than $0.1 \%$ of minimum hourly bacterial production and less than $0.02 \% \mathrm{~d}^{-1}$ of bacterial abundance.

One can also predict that benthic ciliates are not a significant vector for the direct transfer of bacterial production to metazoan food webs. This conclusion is further supported by the low ratio of biomass of heterotrophic ciliates to bacterial biomass $10.6 \%$ for saltmarsh, $2.4 \%$ for saline pond); sediment-ingesting fauna at the study sites would obtain a very small fraction of bacterial production indirectly by ingesting bacterivorous ciliates simultaneously with bacteria.

Ingestion rates may have been underestimated somewhat because of the $30 \mathrm{~min}$ incubation period, during which some digestion of FLB may occur, although measured ingestion rates correspond well to previous estimates of ingestion rates of benthic ciliates (Fenchel 1975). In addition, slurrying of sediment was necessary to disperse FLB and thymidine and could alter ingestion rates. Although bacterial production measured by the thymidine method often has large errors, the overall mean production in saltmarsh sediment for the 4 sampling times has $95 \%$ confidence limits of only $\pm 59 \%$ of the mean; it does not appear that experimental error in measuring bacterial production could account for the imbalance between production and consumption. Because of the great disparity between bacterial production and ciliate consumption, it seems unlikely that these potential errors would alter the conclusions stated above. The strength of the comparison is increased since bacterial production as presented here was not corrected upward for inefficient DNA recovery or isotope dilution.

If ciliates are important bacterivores in other sediments, their ingestion rates or their abundance relative to that of bacteria must be very much greater than found in this study. Additional studies will be required to determine whether higher average ingestion rates occur in natural benthic ciliate assemblages. With regard to abundance, ciliate abundance in the saline pond sediment was very high in comparison to other benthic environments (Kemp 1989, Table 3) while bacterial abundance was typical of shallow-water marine sediment (e.g. Rublee 1982). In addition, most saline 
pond ciliates were bacterivorous. Thus, in one sense the saline pond site provided an example of conditions where ciliate bacterivory was maximized, yet accounted for a small fraction of bacterial production. However, presently available data for benthic ciliates are limited to a few shallow-water environments, and it is possible that in other environments ciliates may be relatively abundant under conditions in which bacterial production is relatively low (e.g. sand beaches, Kemp 1989).

This study did not address the possibility that ciliates may exert an indirect control over bacterial abundance by consuming smaller, potentially important protozoan bacterivores such as microflagellates. As in some pelagic systems, a large fraction of bacterial production may be consumed directly by heterotrophic microflagellates. Preliminary calculations of the potential effects of microflagellate grazing based on a ratio of microflagellate to bacterial abundance of 1:1000 (Fenchel 1986) and on published ingestion rates of watercolumn microflagellates (Fenchel 1982, Sherr et al. 1983, Davis \& Sieburth 1984, Caron et al. 1985, Cynar \& Sieburth 1986, Sherr et al. 1986b), indicate that microflagellates could account for the majority of benthic bacterial production. Alongi (1986), however, has presented contrasting data on microflagellate abundances of less than 1 cell per 1000 bacterial cells. In samples collected for the present study, small heterotrophic protozoa including microflagellates were relatively abundant in saline pond sediment $(1: 2800$ bacteria $)$ but not in saltmarsh sediment $\left(1: 10^{6}\right.$ bacteria). A more thorough evaluation of the role of benthic microflagellates as bacterivores, and in turn as prey of protozoan and metazoan consumers, must await additional estimates of their ingestion rates and abundance in sediment.

Acknowledgements. The author thanks D. Caron, B. Sherr, E. Sherr, and T. Fenchel for their rigorous criticism of earlier versions of the present manuscript, and $\mathrm{R}$. Hodson for the opportunity to participate in the Bahamas cruise. Support for this research was provided by a University of Georgia Marine Institute Postdoctoral Associateship. This report was prepared during an appointment to the Alexander Hollaender Distinguished Postdoctoral Fellowship Program supported by the US Department of Energy, Office of Health and Environmental Research, and administered by Oak Ridge Associated Universities. This is Contribution 611 of the University of Georgia Marine Institute.

\section{LITERATURE CITED}

Alongi, D. M. (1986). Quantitative estimates of benthic protozoa in tropical marine systems using silica gel: a comparison of methods. Estuar coast. Shelf Sci. 23: 443-450

Azam, F., Fenchel, T., Field, J. G., Gray, J., Meyer-Reil, L.-A., Thingstad, F. (1983). The ecological role of bacteria in the sea. Mar. Ecol. Prog. Ser. 10:257-263
Borsheim, K. Y. (1984). Clearance rates of bacteria-sized particles by freshwater ciliates, measured with monodisperse fluorescent latex beads. Oecologia (Berl.) 63: 286-288

Bratbak, G., Dundas, I. (1984). Bacterial dry matter content and biomass estimations. Appl. environ. Microbiol. 48: $755-757$

Caron, D. A., Goldman, J. C., Anderson, O. K., Dennett, M. R. (1985). Nutrient cycling in a microflagellate food chain: II Population dynamics and carbon cycling. Mar. Ecol. Prog. Ser 24: 243-254

Cynar. F. J., McN. Sieburth, J. (1986). Unambiguous detection and improved quantification of phagotrophy in apochlorotic nanoflagellates using fluorescent microspheres and concomitant phase contrast and epifluorescent microscopy. Mar. Ecol. Prog. Ser. 32: 61-70

Davis, P. G., McN. Sieburth, J. (1984). Estuarine and oceanic microflagellate predation of actively growing bacteria: estimation by frequency of dividing-divided bacteria. Mar. Ecol. Prog. Ser. 19: 237-246

Fenchel, T. (1975). The quantitative importance of the benthic microfauna of an arctic tundra pond. Hydrobiologia 46 : $445-464$

Fenchel, T (1980). Suspension feeding in ciliated protozoa: feeding rates and their ecological significance. Microb. Ecol. 6: 13-25

Fenchel, T. (1982). Ecology of heterotrophic microflagellates: II Bioenergetics and growth. Mar. Ecol. Prog. Ser. 8: 225-231

Fenchel, T (1986). The ecology of heterotrophic microflagellates. Adv. microb. Ecol. 9: 57-97

Heinbokel, J. F. (1978). Studies on the functional role of tintinnids in the Southern California Bight. I. Grazing and growth rates in laboratory cultures. Mar. Biol. 47: 177-189

Jonsson, P. (1986). Particle size selection, feeding rates and growth dynamics of marine planktonic oligotrichous ciliates (Ciliophora: Oligotrichina). Mar. Ecol. Prog. Ser 33: $265-277$

Kemp, P. F. (1987). Potential impact on bacteria of grazing by a macrofaunal deposit feeder, and the fate of bacterial production. Mar. Ecol. Prog. Ser. 36: 151-161

Kemp, P. F. (1969). The fate of benthic bacterial production. Rev. Aq. Sci. (in press)

Moriarty, D. J. W., Pollard, P. C. (1981). DNA synthesis as a measure of bacterial productivity in seagrass sediments. Mar. Ecol. Prog. Ser. 5: 151-156

Moriarty, D. J. W., Pollard, P. C. (1982). Diel variation of bacterial productivity in seagrass (Zostera capricorni) beds measured by rate of thymidine incorporation. Mar. Biol. 72: 165-173

Pollard, P. C., Moriarty, D. J. W. (1984). Validity of the tritiated thymidine method for estimating bacterial growth rates: measurement of isotope dilution during DNA synthesis. Appl. environ. Microb. 48: 1076-1083

Porter, K. G., Feig, Y. S. (1980). The use of DAP I for identifying and counting aquatic microflora. Limnol. Oceanogr 25: 943-948

Rivier, A., Brownlee, D. C., Sheldon, R. W., Rassoulzadegan, F. (1985). Growth of microzooplankton: a comparative study of bacterivorous zooflagellates and ciliates. Mar. Microb. Food Webs 1: 51-60

Rublee, P. A. (1982). Bacteria and microbial distribution in estuarine sediments. In: Kennedy, V S. (ed.) Estuarine comparisons. Academic Press, New York, p. 159-182

Sherr, B. F., Sherr, E. B. (1984). Role of heterotrophic protozoa in carbon and energy flow in aquatic ecosystems. In: Klug, M. J., Reddy, C. A. (eds.) Current perspectives in microbial ecology. Am. Soc. Microbiol., Washington, D.C., p. $412-423$ 
Sherr, B. F., Sherr, E. B. (1987). High rates of consumption of bacteria by pelagic ciliates. Nature, Lond. 325: 710-711

Sherr, B. F., Sherr, E. B., Berman, T. (1983). Grazing, growth and ammonium excretion rates of a heterotrophic microflagellate fed with four species of bacteria. Appl. environ. Microbiol. 45: 1196-1201

Sherr, E. B., Sherr, B. F., Fallon, R. D., Newell, S. Y (1986a) Small, aloricate ciliates as a major component of the marine heterotrophic nanoplankton. Limnol. Oceanogr. 31: $177-183$

Sherr, B. F., Sherr, E. B., Andrew, T L., Fallon, R. D., Newell, S. Y. (1986b). Trophic interactions between heterotrophic protozoa and bacterioplankton in estuarine water analyzed with selective metabolic inhibitors. Mar Ecol. Prog. Ser. 32: 169-179

Sherr, B. F., Sherr, E. B., Fallon, R. D. (1987). Use of monodispersed, fluorescently labelled bacteria to estimate in situ protozoan bacterivory. Appl. environ. Microbiol. 53: 958-965

Sieracki, M. E., Haas, L. W., Caron, D. A., Lessard, E. J. (1987). Effect of fixation on particle retention by microflagellates: underestimation of grazing rates. Mar. Ecol. Prog. Ser. 38: 251-258

This article was presented by Dr S. Y. Newell; it was accepted for printing on August 4, 1988 